AGRICULTURE AND BIOLOGY JOURNAL OF NORTH AMERICA

ISSN Print: 2151-7517, ISSN Online: 2151-7525, doi:10.5251/abjna.2013.4.3.320.323

(C) 2013, ScienceHuß, http://www.scihub.org/ABJNA

\title{
Study on comparative plots of the evolution of the first meter of deep ferrailitic soils under the influence of different types of marginal forest areas of the Côte d'Ivoire
}

\author{
S. Bakayoko ${ }^{1,2^{\star}}$, D. Soro ${ }^{1,2}$, K. C. Niangoran ${ }^{2,}$, P. Angui ${ }^{3}$ \\ ${ }^{1}$ Swiss Centre for Scientific Research (Centre Suisse de Recherches Scientifiques) in Côte \\ d'Ivoire, 01 BP 1303 Abidjan 01, Côte d'Ivoire \\ ${ }^{2}$ University of Jean Lorougnon Guédé of Daloa, Department of Soil Science and Geology, BP \\ 150 Daloa, Côte d'Ivoire \\ ${ }^{3}$ University Nangui-Abrogoua of Abidjan, UFR SGE, Laboratory of Geosciences, 02 BP 801 \\ Abidjan 02, Côte d'Ivoire
}

\begin{abstract}
The first meter of deep and developed ferrallitic soils of West-Central Côte d'Ivoire is studied under the two very distinct types of vegetation, the high-slope in an initial state of soil and the bottom-slope on farming plots, which are overlapping in the region. The study mostly concerns the $A$ and $B$ horizons which are thus characterized and compared. Compared to high-slope soils, bottom-slope soils that did not exhibit a sharp textural gradient showed a marked decrease of quartz pebbles and ferruginous or inanganoferric gravels content in the whole profiles. The soils of bottom-slope are deeper and have a good structure with more clay. This is essentially a function of the conditions of humidity and in which they form and evolve, and which intensify the processes of alteration. For the same reason they are generally made up of products of this alteration by particularly resistant minerals, which are, however, already more or less degraded, mainly quartz, and, more rarely, white mica. The microaggregated horizons, characteristic of bottom-slope soils, have a good pore size distribution. Water infiltrates in these horizons through a network of fine interconnected fissures which define microaggregates. Soils properties and soil formation are affected by the topography.
\end{abstract}

Keywords: Ferrallitic soils, Soil properties, Soil quality, Côte d'Ivoire.

\section{INTRODUCTION}

Tropical soils can arise from a wide variety of parent materials, climatic conditions, biotic interactions, landforms, geomorphic elements and soil age. Many of these factors vary more widely in the tropics than in the temperate zone (Richter and Babbar, 1991). Côte d'Ivoire comprises a vast and heterogeneous region, with many of these factors, especially parent materials; landforms, geology and geomorphologic history varying widely (Avenard et al. 1971). On the other hand, factors such as soil temperature and soil moisture regimes are common to many ivorian soils (Avenard et al. 1971). In the early days of soil science in Daloa, they observed ferrallitic soils.

Soil properties and processes can strongly affect land use options. Not all land uses are possible on all soils, and when certain uses do they often require specific management strategies. Because of this, biophysical land evaluation has always strongly emphasized on soil properties combined with climate conditions. Both are difficult to change and especially low input agriculture has to work with climate and soil conditions as given. Notwithstanding, modern technologies allow land managers to overcome a good number of basic constraints, with irrigation being a clear example to alleviate water limitations.

Soils, soil properties and soil formation are affected by: climate, parent material, vegetation, fauna and man, topography and time. The nature and importance of each of these soil forming factors vary, and most soils are still in the process of change.

The nature of a soil, its profile build-up and specific properties are the direct result of several pedogenetic processes linked to the soil forming factors mentioned above. 
This paper provides an up to date review of the most important morpho-pedological characteristics of soil types of this area.

\section{MATERIAL AND METHODS}

Site description: The study areas are located at Daloa (altitude $260 \mathrm{~m}, 06^{\circ} 50^{\prime} 58.53 \mathrm{~N}, 06^{\circ} 26^{\prime} 01.22$ W) at $360 \mathrm{~km}$ from Abidjan (Côte d'Ivoire) northward. The climate is sub-equatorial climate characterized by the alternation of long rainy season (from March to July), a short dry season (from July to August), a short rainy season (from September to October) and a long dry season (from November to February). Mean annual precipitation is $1250 \mathrm{~mm}$ at Daloa. The Harmattan, dry wind blows from December to February during the long dry season. The annual average temperature was $26^{\circ} \mathrm{C}$ with average air moisture of $82 \%$ and a monthly total solar radiation of $386 \mathrm{MJ} / \mathrm{m}^{2}$ from 2008 to 2012.

Research was undertaken on plots chosen according to the operations of clearing carried out and possibility of carrying out a comparative study there. Two sectors are concerned:

- the sector of the high-slope, studies carried out on the blocks of granites with an aim of analyzing the conditions in an initial state.

- the sector of the bottom-slope, studies carried out on farming plots.

Methods: Ten (10) pedological pits of different depth were excavated in the plot to examine the soil profile and ensure that the same soil type was present on each level. Soil samples were taken according to horizon levels (top horizon and subjacent horizon) and analyzed. In each horizon, the soil layer depth, the soil colour using the Munsell value, soil texture (fine versus coarse), the soil structure, the draining soil, the proportion of coarse particles, the porosity quality, biological activity, the compactness, the humidity and hydromorphy. The morpho-pedological characterization indicated the presence of well draining soils and wet in-depth.

All these characteristics are indicated by the observation, the method of the touch and by pricking the knife in the horizon

Depth of horizon was measured by digging small pits, then measuring the depth where soil colour changed using the Munsell soil colour charts (Munsell (1954) cited in Schlichting et al. (1995)).

\section{RESULTS}

In this study, only the morpho-pedological characteristics are considered.

The profiles of the high-slope soil and the bottomslope soil are distinguished by their color, structure or texture (Table 1 and Table 2). The limits between horizons are distinct and sharp. The surface horizon is a dark color, black (7.5 YR 2.5/1 and $10 \mathrm{YR} 2 / 1)$ to very dark gray (7.5 YR 3/1) or brown (7.5 YR 4/3). The colors of the lower horizons are clearer and in the $10 \mathrm{YR} 7 / 4$ (very pale brown) or $7.5 \mathrm{YR} 4 / 4$ (brown). The horizon of alteration, $\mathrm{C}$, is not very thick (less than $20 \mathrm{~cm}$ ) (Table 1) is weakly colored (very pale brown with streaks and diffuse spots of rust color). With depth one may find concretions or indurate horizons. The clay accumulates in a lower horizon (sandy of the high-slope soil and clay-sandy of the bottom-slope soil.

\section{Table 1. Profile of high-slope soil}

\begin{tabular}{|c|c|c|c|c|}
\hline characteristics & $\mathrm{A} 1$ & A3 & B & c \\
\hline horizon thickness & $0.13 \mathrm{~cm}$ & $13-29 \mathrm{~cm}$ & $29-37 \mathrm{~cm}$ & $37-49 \mathrm{~cm}$ \\
\hline colour & 7,5 YR 2,5/1 & 7,5 YR 3/1 & 7,5 YR $3 / 2$ & 10 YR $7 / 4$ \\
\hline internal drainage & well-drained & bad-drained & bad-drained & bad-drained \\
\hline Coarse elements & $\begin{array}{l}\text { little quartz pebbles, } \\
\text { gravels }\end{array}$ & $\begin{array}{l}\text { many quartz pebbles, } \\
\text { gravels }\end{array}$ & $\begin{array}{l}\text { plentiful quartz } \\
\text { pebbles, gravels }\end{array}$ & $\begin{array}{l}\text { plentiful quartz } \\
\text { pebbles, gravels }\end{array}$ \\
\hline texture & sandy & sandy & sandy & sandy \\
\hline structure & sub-angular blocky & fine crumb & fine crumb & fine crumb \\
\hline porosity & good & weak & very weak & bad \\
\hline consistency & friable & sticky & friable & friable \\
\hline biology activity & plentiful fine roots & little fine roots & very little fine roots & not fine roots \\
\hline limit & wavy boundary & wavy boundary & wavy boundary & wavy boundary \\
\hline
\end{tabular}

Thickness of the A1-horizon ranges from $13 \mathrm{~cm}$ (high-slope soil) to about $16 \mathrm{~cm}$ (bottom-slope soil). Solum thicknesses of the bottom-slope soil exceed the depth of the high-slope soil horizons.

The sandy-textured, weakly-structured upper profile of these soils has a thickness range of 13 to more than $49 \mathrm{~cm}$. and a texture that infrequently is finer than loamy very fine sand.

For bottom-slope soil, the vegetation cover is thicker, the clay content higher and the drainage better. 
Table 2. Profile of bottom-slope soil

\begin{tabular}{cccc}
\hline Horizons & A1 & A3 & B \\
\hline characteristics & $0-16 \mathrm{~cm}$ & $16-63 \mathrm{~cm}$ & $63-72 \mathrm{~cm}$ \\
horizon thickness & 10 YR $2 / 1$ & $7,5 \mathrm{YR} 4 / 3$ & $7,5 \mathrm{YR} 4 / 4$ \\
colour & well-drained & well-drained & bad-drained \\
internal drainage & not & little quartz & not \\
Coarse elements & clay-sandy & clay-sandy & clay-sandy \\
texture & well structured & little massive & little massive \\
structure & good & medium & bad \\
porosity & friable & little sticky & sticky \\
consistency & plentiful fine roots & mean fine roots & little fine roots \\
biology activity & wavy boundary & wavy boundary & wavy boundary \\
limit & & &
\end{tabular}

\section{DISCUSSION}

Soil colour is often used as the highest categorical level in many soil classification systems, e.g. the concept of the Russian chernozem was centered around the thick dark soils of the Russian steppe and the Mollisol order of the US soil taxonomy is specifically defined to include most soils with relatively thick, dark surface horizons (Schulze et al., 1993). Generally good soil conditions are associated with dark brown colours near the soil surface, which is associated with relatively high organic matter levels, good soil aggregation and high nutrient levels (Peverill et al. 1999). Schulze et al. (1993) found that within similar landscapes and soil texture classes; there was a good linear correlation between Munsell soil colour and Soil organic matter for Ap horizons from Indiana and Illinois.

The effect of usually dark brown or black SOM on soil colour is important not only for soil classification purposes, but also for ensuring good thermal properties, which in turn contribute to soil warming and promote biological processes (Baldock and Nelson, 1999).

Naturally, dark-coloured soils absorb more energy than light-coloured ones. However, this does not imply that dark-coloured soils are always warmer: since dark-coloured soils usually have a higher amount of organic matter, which holds comparatively larger amounts of water, a greater amount of energy is required to warm darker soils than lighter-coloured ones (Brady, 1990). Thus, the thermal property of soil is to a large degree influenced by water content, soil texture (fine versus coarse) and soil colour.

Organic matter (OM) accumulates in the soil as litter at the surface, and as decaying roots and microbial biomass (microbes, fungi, etc.). This is the result of the balance of production, decomposition and mixing of organic substances and soil material.

Decomposition and mixing of $\mathrm{OM}$ are mainly due to the soil micro- and meso-fauna and are enhanced by oxygen and nutrient availability, high temperature and low amounts of $\mathrm{Fe}^{3+}$ and $\mathrm{Al}^{3+}$ bound to the organic matter. If one or more of these factors are not optimal in the soil, OM decay and mixing are hampered and this leads to organic matter accumulation. In terms of land use the nature of the top soil is essential as it contains most nutrients, and therefore land use types leading to a decline of $\mathrm{OM}$ in the soil deteriorate quickly.

Soil structural stability refers to the resistance of soil to structural rearrangement of pores and particles when exposed to different stresses (e.g. cultivation, trampling/compaction, and irrigation). The interrelationship between SOC and soil structure and other physical properties has been extensively studied, and excellent reviews can be found in Angers and Carter (1996).

The morphological and physical characteristics are subject to the most intense and rapid disturbances due to degradation and widening of the structure decrease in porosity and permeability. The ferrallitic soils in central Côte d'lvoire are characterized by a very small range of optimum humidities. The phenomena of fragmentation, compaction and consolidation play an essential role in the differentiation of the microstructures.

Pedogenesis progresses in time and the longer it acts the better a logical evolution in soil development can be observed, from young to older and more mature soils in time. This is reflected in so-called chronosequence studies, like on river terraces where all conditions are assumed to be equal except time. A good example of such a study was made by Jongmans et al. (1991) in the Allier basin in France where a shift was observed from recent soils with only an organic surface soil development, towards a textural differentiation in a later phase, and leading in time to temporary water stagnation and hydromorphic 
conditions; ultimately, it involved further leaching, texture differentiation and finally podzolization. As a result, the agricultural soil potential also changed in time.

High topographic stability combined with continuous hot and wet weather has also already resulted in a deep weathering and leaching of parent material with lack of erosion over the generally flat topography eliminating bedrock.as a source of nutrients for this region.

\section{CONCLUSION}

The structural, organo-biological characteristics are subject to the most rapid and intense disturbances due to topography. The degradation of the soil general characteristics leads to a downward leveling. Therefore, the soils which are subject to the least favourable conditions at the initial state show the lowest relative degradation under the influence of erosion. The soil evolution under the influence of topography depends both on the soil condition and its environment at the initial state and on the conditions of subsequent cultivation (methods and constraints). The study of the processes of evolution concerning the soils suggests that these two types of determinants should be taken into account.

\section{REFERENCES}

Angers DA, Carter MR (1996). Aggregation and organic matter storage in cool, humid agricultural soils. In 'Structure and organic matter storage in agricultural soils. (Eds M. R. Carter and B. A. Stewart) pp. 193211. (CRC Press: Boca Raton.)
Avenard JM, Edlin M, Girard G, Sircoulon J, Touchebeuf P, Guillaumet JL, Adjanohoun E, Perraud A (1971). Le milieu naturel de la Côte d'Ivoire. éd. ORSTOM, Paris, $391 \mathrm{p}$.

Baldock JA, Nelson PN (1999). Soil Organic Matter. In 'Handbook of Soil Science. (Ed M. E. Sumner.) p. B25B84. (CRC Press: Boca Raton, USA.)

Brady NC (1990). 'The nature and properties of soils.' (MacMillan Publishing Company: New York.)

Jongmans AG, Feijtel TC, Miedema R, van Breemen N, Veldkamp A (1991). Soil Formation in a Quaternary Terrace Sequence of the Allier, Limagne, France. Geoderma. 49: 215-239 [Paper describing a typical temperate region chronosequence, based on soil processes and genesis].

Peverill KI, Sparrow LA, Reuter DJ (1999). 'Soil Analysis. An Interpretation Manual.' (CSIRO Publishing: Collingwood.)

Richter DD, Babbar, LI (1991) Soil diversity in the tropics, Adv. Ecol. Res. 21:315-389.

Schlichting E, Blume HP, Stahr K (1995). Bodenkundliches Praktikum: Eine Einführung in pedologisches Arbeiten für Ökologen, insbesondere Land und Forstwirte und für Geowissenschaftler. Blackwell-Wissenschafts Verlag, Berlin.

Schulze DG, Nagel LL, van Scoyoc GE, Henderson TL, Baumgardner, MF, Stott DE (1993). Significance of organic matter in determining soil color. In 'Soil color. Vol. SSSA Special Publication number 31.' (Eds J. M. Bigham and E. J. Ciolkosz.) pp. 71-90. (Soil Science Society of America: Madison, WI.). 